\title{
CAEP position statement on cellphone use while driving
}

\author{
Dayan Huang; ${ }^{*}$ Atul K. Kapur, MD, MSc; ${ }^{\dagger}$ Patrick Ling, MD; ${ }^{\ddagger}$ Roy Purssell, MD; ${ }^{\S}$ Ryan J. Henneberry, MD; \\ Chantelle R. Champagne; ${ }^{* *}$ Victoria K. Lee; ${ }^{* *}$ Louis H. Francescutti, MD, PhD, MPH ${ }^{\dagger \dagger}$
}

VERSION FRANÇAISE À LA PAge 371

\section{SUMMARY}

Distracted driving caused by cellphone use is a significant source of needless injuries. These injuries place unnecessary financial burden, emotional stress and health care resource misuse on society. This paper states the Canadian Association of Emergency Physician's (CAEP's) position on cellphone use while driving.

In recent years, numerous studies were conducted on the danger of cellphone use while driving. Research has shown that cellphone use while driving negatively impacts cognitive functions, visual fields, reaction time and overall driving performances. Some studies found that cellphone use is as dangerous as driving under the influence of alcohol. Moreover, vehicle crash rates were shown to be significantly higher when drivers used cellphones.

Countermeasures have been implemented in recent years. Over 50 countries worldwide have laws limiting the use of cellphones while driving. Six Canadian provinces, Newfoundland and Labrador, Nova Scotia, Quebec, Ontario, British Columbia and Saskatchewan, currently have legislation prohibiting cellphone use. Other provinces are considering implementing similar bans.

As emergency physicians, we must advocate for injury prevention. Cell phone related road traumas are avoidable. CAEP supports all measures to ban cellphone use while driving.

\section{CAEP POSITION}

The Canadian Association of Emergency Physicians recommends the following measures:
1. CAEP advocates for a total ban on hand-held and handsfree cellphone use while driving.

2. CAEP supports public awareness campaigns to inform people about the dangers of using cellphones and other hands-free electronic devices while driving.

3. CAEP supports discussions and seminars on the dangers of cellphone use while driving at future national conferences to raise awareness within the medical community.

4. CAEP supports continuing research into the danger of distracted driving.

5. CAEP supports legislations and policies banning all use of cellphones while driving.

Board approved Apr. 13, 2010

\section{INTRODUCTION}

The consequences of motor vehicle collisions (MVCs) are often devastating to families, physicians and the entire health care team. Emergency physicians, who often witness the outcomes of collisions first hand, especially recognize the burden of MVCs on society. The economic burden of collisions in Canada is estimated to be $\$ 62.7$ billion each year, which represents close to $4.9 \%$ of Canada's 2004 gross domestic product. $^{1}$ According to Statistics Canada, the number of deaths related to motor vehicle accidents from 2000 to 2005 totalled 18 643. Of these, 4479, or nearly onequarter (24\%), involved the age group 15 to 24 years. ${ }^{2}$

Since the introduction of cellphones in 1983, the user rate has been increasing by approximately $40 \%$ per

\footnotetext{
* Medical Student, College of Medicine, University of Saskatchewan, Saskatoon, Sask., †Assistant Professor, Department of Emergency Medicine, University of Ottawa, Ottawa, Ont., $¥$ Clinical Associate Professor, Academic Department of Family Medicine, University of Saskatchewan, Saskatoon, Sask., §Associate Professor, Department of Emergency Medicine, University of British Columbia, Vancouver, BC, ๆAssistant Professor, Department of Medicine, Dalhousie University, Halifax, NS, **Medical Student, Faculty of Medicine and Dentistry, University of Alberta, Edmonton, Alta., and ††Professor, University of Alberta, Edmonton, Alta., and Emergency Physician, Royal Alexandra Hospital, Edmonton, Alta.
}

This article has been peer reviewed.

CJEM 2010;12(4):365-70 
year. More than $85 \%$ of cellphone users admitted to using their phone on at least one occasion while driving, and more than $27 \%$ used their phones during half or more of their trips. Driver distraction, including the use of cellphones and other electronic devices, is suggested to be responsible for $25 \%$ to $30 \%$ of collisions, with some estimates as high as $90 \%$. $^{3}$

The impact of cellphone use while driving has become increasingly apparent in recent years through hundreds of research studies. As a result, 6 Canadian provinces have passed laws to restrict hand-held cellular phone use: Newfoundland and Labrador, Nova Scotia, Quebec, Ontario, British Columbia and Saskatchewan. Several other jurisdictions are considering similar legislation. In addition, Transport Canada recommends a total ban on cellphone use while driving.

As emergency physicians, advocacy for public health and safety falls under our ethical duty. Therefore, the Canadian Association of Emergency Physicians (CAEP) promotes safe driving practices and supports a ban on hand-held and hands-free cellphone use while operating motor vehicles.

\section{THE EVIDENCE}

\section{a) Cognitive function studies}

Many studies have shown the detrimental effects of cognitive distraction on driving. A 2007 study used functional magnetic resonance imaging (fMRI) to investigate the impact of concurrent auditory language comprehension on the brain activity while subjects performed a simulated driving task. The subjects listened to spoken sentences that they were asked to judge as true or false. While the subjects were responding, the concurrent fMRI showed reduced brain activity in the cortical area responsible for driving. ${ }^{4}$ The mental resources required for making simple true or false decisions is demonstrably less intensive than an actual phone conversation where dialing and talking are also involved.

In another study, experimenters used a driving simulator and instructed the subjects to follow a truck on a highway while employing 3 types of verbal distracters during a phone conversation: casual conversation, simple arithmetic number guessing and number adding. The results showed that verbal and cognitive distractions associated with cellphone use impaired driving skill and performance. These included the driving speed, headway (distance between the lead car and the manipulated car), brake reaction time and number of collisions with the lead car. In general, the higher the cognitive load involved in the dialogue, the worse the driving performance. ${ }^{5}$

A driver's visual field can also be negatively impacted by conversing on a cellphone. Researchers found the addition of a conversational task led to large reductions in the functional field of view, which may be an important mechanism involved in increased risk for MVCs with in-car phone use. ${ }^{6}$

In addition to having visual field impairment, individuals with cognitive distractions fail more often to appreciate and comprehend the visual information presented to them. An article published in the Journal of Experimental Psychology found that cellphone conversations impaired explicit recognition memory for roadside billboards due to reduced attention to foveal information. Therefore, even when participants direct their gaze at objects in the driving environment, they may fail to perceive them because attention is directed elsewhere.

\section{b) Cellphone use provides considerable distraction}

A 2003 study found distracted drivers were slower to respond to light changes. They used brakes more intensely and were $15 \%$ more likely to be less responsive to stoplights. ${ }^{8}$ Hands-free devices appear to carry the same risks as hand-held devices. A 2004 study investigated drivers talking on the phone and showed their reactions were $18 \%$ slower. They took $17 \%$ longer to recover the speed that was lost following braking. There was also a 2-fold increase in the number of rearend collisions. ${ }^{9}$

Epidemiological evidence suggests that the relative risk of being in a collision while using a cellphone is similar to the hazard of driving with a blood alcohol level at the legal limit. One study found that when drivers were conversing on either a hand-held or handsfree cellphone, their braking reactions were delayed and they were involved in more traffic collisions. In contrast, when drivers were intoxicated from ethanol, they exhibited a more aggressive driving style, following closer to the vehicle immediately in front of them and applying more force while braking. These behaviours effectively contribute to significant delays in reaction time, among other impairments. The study concluded that when driving conditions and time on task were controlled for, the impairments associated with using a cellphone while driving can be as profound as those associated with driving while drunk. ${ }^{10}$

This finding was echoed by another study in 2008 . 
The examiners studied the effect of reading or writing text messages while driving. The results showed a $35 \%$ decrease in reaction time, decreased ability to maintain lateral vehicle control, and an increased likelihood of drifting into another lane. The authors concluded that the serious impairment on drivers' judgment may be comparable to, or even greater than, driving at the legal alcohol limit or under the influence of marijuana. ${ }^{11}$

Some may argue that talking on the cellphone is no more distracting than talking to a passenger. However, a 2008 study found that during passenger conversations, the production of speech by the driver and the complexity of speech used by both the driver and the passenger dropped in response to an increase in the demand of traffic. Moreover, the topics of passenger conversations often included the traffic, as passengers helped the driver navigate and warned the driver of hazards. When compared with no distractions, cellphone use negatively impacted lane keeping, increased following distance and impaired navigation; on the other hand, passenger conversation had little effect on all 3 measures. ${ }^{12}$

\section{c) On the road}

In one survey of American youth, $83 \%$ of teens admitted to talking on their cellphone while driving, but only $43 \%$ said they were confident in their driving ability while talking. Similarly, $68 \%$ of teens admitted to texting while driving, but only $21 \%$ said they were confident in their driving ability while texting. ${ }^{13}$ These alarming statistics show that cellphone use while driving has become the social norm for teenagers and will likely compound their already elevated risk of being involved in an MVC.

Nevertheless, it is not only the young, inexperienced drivers who are impaired by cellphone conversations. Strayer and Drews ${ }^{14}$ have shown equivalent driving impairment in both younger and older drivers engaging in cellphone conversations while driving. A 2005 study based in Quebec pointed out that the relative risk of all collisions was higher for cellphone users than for nonusers. The relative risk for all collisions, and for injury resulting from collisions, was 38\% higher for cellphone users. There is a dose-response relationship between the frequency of cellphone use and crash risks. ${ }^{15}$

A 1997 New England Journal of Medicine study investigated 699 people from the Toronto area involved in noninjury traffic collisions. The study found over $24 \%$ of drivers had used cellphones within a 10-minute period preceding their collision. The study concluded that cellphone use in motor vehicles quadruples the risk for collision. Additionally, there was no difference in collision risk when comparing hands-free devices to hand-helds. ${ }^{16}$

A more recent 2005 study in Western Australia examined drivers who owned or used mobile phones and had been involved in road crashes necessitating a hospital visit. The findings showed a striking resemblance to the 1997 study. Authors concluded that cellphone use up to 10 minutes before a crash was associated with a 4 -fold increase in the likelihood of crashing; again, hands-free devices were not found to be any safer. ${ }^{17}$

\section{SUCCESSES IN MOTION}

\section{a) Canadian statistics}

Canadians are aware of the risks associated with cellphone use while driving. According to the Traffic Injury Research Foundation, $66 \%$ of Canadians acknowledge that such practice is a very serious road safety problem. Unfortunately this awareness has little impact on behaviour. A 2006 survey by the same organization found that $37 \%$ of drivers reported using a cellphone while driving in the past week. ${ }^{18}$

Across Canada, the average driver cellphone use was $5.9 \%$ in urban areas and $2.8 \%$ in rural areas. Urban Alberta had the highest rate of phone use at $11.7 \%$. Nova Scotia had the lowest rate of $2.2 \%$ for urban and $0.8 \%$ for rural areas. Cell phone usage was inversely correlated with age. In Canadian drivers younger than $25,6.7 \%$ would use cellphones, compared to $2.4 \%$ of drivers older than $50 .{ }^{19}$

\section{b) Cellphone use while driving legislation in Canada}

Driver cellphone use has been a long-standing issue in Canada. Newfoundland and Labrador was the first jurisdiction to realize this problem. A cellphone ban introduced through Bill 15 under the Highway Traffic Act received Royal Assent on Dec. 19, 2002. The new law became effective within the following months. Ninetyfive percent of Newfoundlanders and Labradorians believed cellphone use by drivers is a serious safety concern. However, $37 \%$ of people felt hands-free devices were acceptable. As a result, the legislation only banned the use of hand-held devices to avoid public controversy. ${ }^{20}$ Offenders would be fined anywhere from $\$ 100$ to $\$ 400$. In addition, 4 demerit points would be assigned. ${ }^{21}$

Following the example set by Newfoundland and 
Labrador, Nova Scotia made amendments to its Motor Vehicle Act, and received Royal Assent on Dec. 7, 2007. The cellphone ban took effect on Apr. 1, 2008. Nova Scotia also allowed hand-free device communications, and exempted emergency cellphone use. However, "text messaging" was specifically mentioned in its ban. ${ }^{21}$ Penalties were $\$ 50$ for the first offence, $\$ 100$ for the second, and $\$ 200$ for the third and subsequent offences. ${ }^{22}$

Quebec has made similar amendments to its Highway Safety Code. It received Royal Assent on Dec. 23, 2007, and the ban took effect on Apr. 1, 2008. Quebec made exceptions for operators of emergency vehicles to ensure the quality of their performance. Quebec considers simply holding a cellphone as a presumption of its "use" and therefore constitutes an offence. ${ }^{21}$ Quebec allowed a 3-month grace period, during which offenders would receive a warning. Effective Jul. 1, 2008, offenders are fined $\$ 80$ to $\$ 100$ and assigned 3 demerit points. Although the new law did not ban hands-free devices, the province strongly recommended against their use. ${ }^{23}$

Ontario proposed its ban on the use of hand-held devices to talk, text or email while driving on Oct. 28, 2008..$^{21}$ On Oct. 26, 2009, the law became official under Bill 118 - Countering Distracted Driving and Promoting Green Transportation Act. A 3-month education period followed the initial ban. As of February 2010, police started issuing tickets, with offender fines up to $\$ 500 .^{24}$ In addition, drivers who place others at risk can be charged with Careless Driving and face fines of up to $\$ 1000$, 6 demerit points, a driver's licence suspension and possible jail time. If convicted of Dangerous Driving, drivers could face a penalty of up to $\$ 2000$ and 5 years in jail. ${ }^{25}$ Similar to other provinces, exemptions were made for police, paramedics, firefighters and emergency 911 calls. Moreover, no restrictions were placed on hand free devices. ${ }^{24}$

Manitoba made comparable amendments to its Highway Traffic Act with the introduction of Bill 5 on Nov. 27, 2008. Once again, an exception was made for emergency calls and use by police, fire and ambulance personnel. ${ }^{21,26}$ The amendment passed Royal Assent on Jun. 11, 2009. An extensive public education campaign began Sep. 21, 2009. The law will commence during the first half of $2010 .{ }^{26}$

Prince Edward Island currently has no universal cellphone law; however, a ban on cellphone use while operating vehicles for Stage 1 drivers or newly licensed drivers has been in place since 2007..$^{21,27}$ A penalty of $\$ 100$ is charged for every offence. ${ }^{4}$ Prince Edward Island is currently considering a province-wide cellphone ban for all drivers. ${ }^{28}$

Other provinces are following the trend. Saskatchewan passed legislation in the winter of 2009, and the new law banning hand-held devices was in place starting Jan. 1, 2010. ${ }^{29}$ In 2009, British Columbia was also considering a cellphone ban. The province was under heavy public pressure from BC Safety Council, BC Medical Association and BC Association of Chiefs of Police. ${ }^{30}$ A new law banning hand-held devices came into effect Jan. 1, $2010 .{ }^{31}$ In Alberta, advocates for driver cellphone ban echo other provinces. ${ }^{32}$ In May 2009, Strathcona County became the first municipality in Alberta to ban handheld devices while driving. ${ }^{33}$ The latest study published in September 2009 from the University of Calgary concluded that a cellphone ban will be cost-effective from a societal perspective. ${ }^{34}$

\section{c) Cellphone use while driving legislation worldwide}

On an international scale, over 50 countries have already enacted cellphone bans while driving. ${ }^{35}$ In the United States, 5 states have established laws prohibiting driver cellphone use - California, Connecticut, New Jersey, New York and Washington. In addition, 17 states have laws prohibiting new drivers and school bus drivers from using both hand-held and hands-free devices. ${ }^{21,36,37}$

\section{CONCLUSION}

Cellphone use while driving poses threats to the safety of drivers, their passengers and other road users. The consequences include needless injuries, excessive financial burden and additional drain on health care resources. As emergency physicians, public safety falls under our ethical duty. Cellphone related road trauma and accidents are preventable. CAEP advocates for a total ban on hand-held and hands-free cellphone use while driving.

The most effective measure for injury is prevention, and the success of prevention lies heavily in promoting safe practices. People need to be made aware of the risks of cellphone use while driving and encouraged to make safer choices through education and policy. Public awareness campaigns focused on the consequences of driving while talking or texting on a cellphone are an important step in promoting safe driving practices. CAEP supports public awareness campaigns to inform people about the dangers of using cell- 


\section{phones and other hands-free electronic devices while driving.}

The danger of cellphone use while driving is an issue that deserves attention from physicians on a national level. In order to raise awareness within the medical community and attract more interested health care personnel, CAEP supports discussions and seminars on the dangers of cellphone use while driving at future national conferences.

Over the past few years, numerous studies have been conducted on the danger of cellphone use while driving. As a result, more scientific evidence surfaced and attracted attention from both public organizations and government jurisdictions worldwide. With ongoing research, the danger of cellphone use while driving will only become more apparent. CAEP supports continuing research into the danger of distracted driving.

Over 50 countries worldwide have already banned the use of cellphones while driving. Canada started to take actions in recent years. Six provinces have already established laws banning cellphone use. In addition, other provinces are considering similar actions in the near future. CAEP supports legislations and policies banning the use of cellphones while driving.

The evidence to date is sufficiently compelling to demand that immediate action be taken for a total ban, including both band-held and hands-free, of cellphone use while driving. Ultimately, to successfully reduce the risks associated with cellphone use while driving, a combination of physician advocacy, public education, medical community awareness, continued research and change in legislations is required.

\section{Competing interests: None declared.}

Keywords: cellphone, position statement, safety, driving

\section{REFERENCES}

1. Analysis and estimation of the social cost of motor vebicle collisions in Ontario - final report. Ottawa (ON): Transport Canada; 2007.

2. Table 102-0540. Deaths, by cause, Chapter XX: External causes of morbidity and mortality (V01 to Y89), age group and sex, Canada, annual (number). Ottawa (ON): Statistics Canada Available: http://cansim2.statcan.gc.ca/cgi-win/cnsmcgi.exe? Lang=E\&RootDir=CII/\&Result Template $=\mathrm{CII} / \mathrm{CII} \_$_ Arr ay_Pick=1\&ArrayId=1020540 (accessed 2010 Apr. 3).

3. National Highway Traffic Safety Administration (NHTSA). An investigation of the safety implications of wireless communications in vebicles. Washington (DC): US Department of Transportation, 1998. Available: www.nhtsa.dot.gov/people/injury /research/wireless/index.html (accessed 2006 Nov. 9).

4. Just MA, Keller TA, Cynkar J. A decrease in brain activation associated with driving when listening to someone speak. Brain Res 2008;1205:70-80.

5. Lin CJ, Chen HJ. Verbal and cognitive distractors in driving performance while using hands-free phones. Percept Mot Skills 2006;103:803-10.

6. Atchley P, Dressel J. Conversation limits the functional field of view. Hum Factors 2004;46:664-73.

7. Strayer DL, Drews FA, Johnston WA. Cell phone-induced failures of visual attention during simulated driving. I Exp Psychol Appl 2003;9:23-32.

8. Hancock PA, Lesch M, Simmons L. The distraction effects of phone use during a crucial driving maneuver. Accid Anal Prev 2003;35:501-14.

9. Strayer DL, Drews FA. Profiles in driver distraction: effects of cell phone conversations on younger and older drivers. Hum Factors 2004;46:640-9.

10. Strayer DL, Drews FA, Crouch DJ. A comparison of the cell phone driver and the drunk driver. Hum Factors 2006;48:381-91.

11. Reed N, Robbins R. The effect of text messaging on driver behavior: a simulator study. Berkshire (UK): Transport Research Laboratory; 2008.

12. Drews FA, Pasupathi M, Strayer DL. Passenger and cell phone conversations in simulated driving. I Exp Psychol Appl 2008;14:392-400.

13. Shifting teen attitudes: 2009. State of teen driving. Northbrook (IL): The Allstate Foundation. Available: www.allstate.com /foundation/teen-driving/Shifting-Teen-Attitudes.aspx (accessed 2010 Apr. 3).

14. Strayer DL, Drews FA. Profiles in driver distraction: effects of cell phone conversations on younger and older drivers. Hum Factors 2004;46:640-9.

15. Laberge-Nadeau C, Maag U, Bellavance F, et al. Wireless telephones and the risk of road crashes. Accid Anal Prev 2003;35:649-60.

16. Redelmeier DA, Tibshirani RJ. Association between cellulartelephone calls and motor vehicle collisions. $N$ Engl $7 \mathrm{Med}$ 1997;336:453-8.

17. McEvoy SP, Stevenson MR, McCartt AT, et al. Role of mobile phones in motor vehicle crashes resulting in hospital attendance: a case-crossover study. BMJ 2005;331:428.

18. Vanlaar W, Simpson HM, Mayhew D, et al. The road safety monitor 2006: distracted driving. Ottawa (ON): Traffic Injury Research Foundation; 2006.

19. Burns P, Lecuyer J, Chouinard A. Observed driver phone use rates in Canada. Ottawa (ON): Transport Canada, 2008.

20. Government of Newfoundland and Labrador. Bill passed to 
limit cell phone use by drivers. 2002 Dec 20. Available: www .releases.gov.nl.ca/releases/2002/gsl/1220n03.htm (accessed 2009 Oct. 14).

21. William M. Legislative summary: cell phones and other driving distractions. Toronto (ON): Workplace Environment Health \& Safety Reporter; 2008. p. 2675.

22. Government of Nova Scotia. Legislation prohibits using hand-held cellphones while driving. 2008 Feb 21. Available: www.gov.ns.ca/news/details.asp?id=20080221003 (accessed 2009 Oct. 15).

23. An act to amend the Highway Safety Code and the regulation respecting demerit points. Québec (QC): Transport Quebec; 2007. Available: www.mtq.gouv.qc.ca/portal/page/portal /grand_public_en/vehicules_promenade/securite_routiere /projet_loi_42_csr\#cell (accessed 2009 Oct. 15).

24. Government of Ontario. Ban on hand-held devices starts in October. Newsroom 2009 Sept. 30. Available: http:// news.ontario.ca/mto/en/2009/09/ban-on-hand-held-devices -starts-in-october.html (accessed 2009 Oct. 18).

25. Government of Ontario. About the Countering Distracted Driving and Promoting Green Transportation Act. Newsroom 2008 Oct. 28. Available: www.news.ontario.ca/mto/en /2008/10/about-the-countering-distracted-driving-and-prom oting-green-transportation-act-2008.html (accessed 2009 Oct. 18).

26. Government of Manitoba. See the signs. Available: www .gov.mb.ca/seethesigns/index.html (accessed 2010 Apr. 3).

27. Graduated driver licensing regulations P.E.I. Reg. EC225/07. Ottawa (ON): Canadian Legal Information Institute; 2007. Available: www.canlii.org/en/pe/laws/regu/pei-reg-ec225 -07/latest/pei-reg-ec225-07.html (accessed 2009 Oct. 16).

28. MLAs debate reach of cell phone ban on P.E.I. CBC news 2008 Sep. 4. Available: www.cbc.ca/canada/prince-edward -island/story/2008/09/04/pe-cellphone-driving.html (accessed 2009 Oct. 15).
29. Government of Saskatchewan. Government passes cell phone legislation. 2009 Nov. 25. Available: www.gov.sk.ca /news? newsId=2fb0a99b-4e33-4b12-ab8e-ad6d32a 11958 (accessed 2010 Apr. 3).

30. Shearon K. B.C. to ban cell phone use by drivers. The Province 2009 Aug 27. Available: www2.canada.com/the province/news/story.html? id=812df75a-f52c-4e30-b748-754 f3f5d2956 (accessed 2010 Apr. 5).

31. British Columbia Government. Final countdown to cell phone ban while driving. 2009 Dec 21. Available: www2.news.gov.bc.ca/news_releases_2009-2013/2009PSSG 0044-000783.pdf (accessed 2010 Apr. 5).

32. Coalition for cell phone free driving [home page]. Available: www.cellphonefreedriving.ca (accessed 2009 Oct. 9).

33. Strathcona County first in Alberta to ban cell phone use while driving. $C B C$ news 2009 May 29. Available: www.cbc.ca /canada/edmonton/story/2009/05/20/edmonton-strathcona -county-cell-phone-ban.html (accessed 2009 Oct. 11).

34. Sperber D, Shiell A, Fyie K. The cost-effectiveness of a law banning the use of cellular phones by drivers. Health Econ. 2009;Sep 17. [Epub ahead of print] PMID: 19764069.

35. Cellular-news. Countries that ban cell phones while driving. Available: www.cellular-news.com/car_bans (accessed 2009 Oct. 12).

36. Ontario Medical Association. Cellular phone use and driving: a dangerous combination. Toronto (ON): The Association; 2008.

37. Governors Highway Safety Association. Cell phone driving laws. Available: www.ghsa.org/html/stateinfo/laws/cell phone_laws.html (accessed 2010 Apr. 3).

Correspondence to: Vera Klein, Executive Director, Canadian Association of Emergency Physicians, Ste. 104, 1785 Alta Vista Dr., Ottawa ON K1G 3Y6; fax 613 523-0190; vklein@caep.ca; www.caep.ca 